\title{
P02-002 - IL36RN mutations in patients with DITRA
}

\author{
JI Arostegui ${ }^{1}$, MA Vicente-Villa ${ }^{2}$, A Chaves ${ }^{3}$, E Gonzalez-Roca ${ }^{1}$, E Ruiz-Ortiz ${ }^{1}$, J Rius ${ }^{1}$, S Plaza ${ }^{1}$, \\ MA Gonzalez-Enseñat ${ }^{2}$, J Yague ${ }^{1}$ \\ From 7th Congress of International Society of Systemic Auto-Inflammatory Diseases (ISSAID) \\ Lausanne, Switerland. 22-26 May 2013
}

\section{Introduction}

Loss-of-function mutations in the IL36RN gene define a novel recessively inherited autoinflammatory syndrome named deficiency of IL-36 receptor antagonist (DITRA). This genetically determined deficiency was first described in a subgroup of patients with generalized pustular psoriasis. It is a life-threatening condition characterized by recurrent episodes of severe skin inflammation, with pustule development, associated with fever, malaise, extracutaneous involvement, neutrophilia and a marked acute phase response.

\section{Case report}

\section{Methods}

The patients' data as well as the outcome of the administered treatments were collected from charts reviews. $I L 36 R N$ analysis was performed by means of Sangerbased sequencing.

\section{Results}

We describe two unrelated families with patients diagnosed as suffering from generalized pustular psoriasis. The family 1 is a large consanguineous Algerian family with several affected members living in Algeria and in Spain. The propositus is a 13 year-old child who had suffered from two episodes of severe skin inflammation, with disseminated pustular development and systemic features that required hospital admission. Once DITRA was described in 2011, this diagnosis was suggested for this patient. IL36RN mutational analyses revealed a homozygous $\mathrm{T}$-to- $\mathrm{C}$ transition in the exon 3 (at c.80 position), which provokes the leucine-to-proline variant at residue 27 (p.L27P) of the protein. This missense variant has been previously identified as a true diseasecausing mutation in other Maghrebian (Tunisian) families with DITRA.

The family 2 is an apparent non-consanguineous Spanish family with only one affected individual. The patient is a 15 years-old girl who suffered since 6 months of age from recurrent and severe episodes of generalized pustular psoriasis that required recurrent hospital admissions. She has been treated with different drugs, including methotrexate, acitretin, cyclosporin, phototherapy, etanercept, infliximab, adalimumab and ustekinumab, with variable and limited efficacy. As a DITRA diagnosis was suggested, IL36RN analysis was performed. This study revealed an apparent homozygous $7 \mathrm{bp}$ deletion in the exon 5 (c.420_426del), which should provoke a frameshift of the normal open reading frame. Genetic studies are currently ongoing to elucidate the intrafamilial mutational segregation pattern.

\section{Discussion}

We describe two novel families affected by the novel autoinflammatory disease called DITRA. The disease started in these patients during childhood as severe episodes of generalized pustular skin rash and systemic features that required hospital admissions. We identified a novel IL36RN mutation in the Spanish family, and the already known missense p.L27P mutation in the Algerian family. This insight probably expands the founder effect of this IL36RN mutation to other Maghrebian populations than Tunisian people.

\section{Disclosure of interest}

None declared.

${ }^{1}$ Immunology, Hospital Clinic, Barcelona, Spain

Full list of author information is available at the end of the article 


\section{Authors' details}

${ }^{1}$ Immunology, Hospital Clinic, Barcelona, Spain. ${ }^{2}$ Dermatology, Hospital Sant Joan de Deu, Esplugues, Spain. ${ }^{3}$ Dermatology, Hospital Infanta Cristina,

Badajoz, Spain.

Published: 8 November 2013

\section{References}

1. Marrakchi S, et al: N Engl J Med 2011, 365:620-8.

2. Onoufriadis A, et al: Am J Hum Genet 2011, 89:432-7.

3. Sugiura K, et al: Br J Dermatol 2012, 67:699-701.

doi:10.1186/1546-0096-11-S1-A109

Cite this article as: Arostegui et al:: P02-002 - IL36RN mutations in patients with DITRA. Pediatric Rheumatology 2013 11(Suppl 1):A109.

Submit your next manuscript to BioMed Central and take full advantage of:

- Convenient online submission

- Thorough peer review

- No space constraints or color figure charges

- Immediate publication on acceptance

- Inclusion in PubMed, CAS, Scopus and Google Scholar

- Research which is freely available for redistribution

Submit your manuscript at www.biomedcentral.com/submit
C Biomed Central 